\title{
EFFECT OF STAPHYLOCOCCUS AUREUS INFECTION ON THE SERUM AMYLOID A AND IRON LEVELS IN RABBITS
}

\author{
M. Toneva ${ }^{\text {1* }}$ T. M. Georgieva ${ }^{1}$, V. Marutsova ${ }^{2}$, Vl. Petrov ${ }^{3}$, P. T. Iliev ${ }^{3}$, K. Walshe ${ }^{4}$, \\ N. Nizamov ${ }^{3}$ \\ ${ }^{1}$ Department of Pharmacology, Physiology of the Animals and Physiological Chemistry, Faculty of \\ Veterinary Medicine, Trakia University, Stara Zagora, Bulgaria \\ ${ }^{2}$ Department of Internal Noninfectious Diseases, Faculty of Veterinary Medicine, Trakia University, Stara \\ Zagora, Bulgaria. \\ ${ }^{3}$ Department of Veterinary Microbiology, Infectious and Parasitic Diseases, Faculty of Veterinary \\ Medicine, Trakia University, Stara Zagora, Bulgaria. \\ ${ }^{4}$ Accuplex Diagnostics Ltd, Co.Meath, Ireland
}

\begin{abstract}
The present study was conducted to examine the changes in serum amyloid A (SAA) and iron concentrations during Staphylococcus aureus (S. aureus) infection in rabbits. The experimental procedures were carried out with 12 male New Zealand white healthy rabbits, divided into two equal groups - experimental group ( $\mathrm{n}=6$, rabbits infected with $S$.. aureus) and control group ( $\mathrm{n}=6$, uninfected animals). Blood samples were collected at time 0 (before the infection), 24, 48 and 72 hours and also 7 and 14 days after the infection. The results in infected group showed a significant increase in the levels of SAA at the $24^{\text {th }}$ hour $(\mathrm{p}<0.001), 48^{\text {th }}$ hour $(\mathrm{p}<0.05)$, and $72^{\text {th }}$ hour $(\mathrm{p}<0.05)$ post-infection with mean levels $72.13 \pm 23.29 \mu \mathrm{g} / \mathrm{mL}, 37.57 \pm 31.55 \mu \mathrm{g} / \mathrm{mL}$ and $18.03 \pm 15.15 \mu \mathrm{g} / \mathrm{mL}$ respectively. The iron concentration decreased at the $24^{\text {th }}$ hour and $14^{\text {th }}$ day post-infection, reaching values of $178.8 \pm 87.2 \mu \mathrm{g} / \mathrm{dL}$ $(\mathrm{p}<0.01)$ and $123.33 \pm 17.8 \mu \mathrm{g} / \mathrm{dL}(\mathrm{p}<0.05)$ respectively. In conclusion changes in SAA and Fe levels may be used as valuable biochemical indicators for the diagnosis and prognosis of staphylococcosis in rabbits.
\end{abstract}

Key words: Staphylococcus aureus, rabbits, serum amyloid A, iron, SAA

\section{INTRODUCTION}

Bacterial skin diseases in rabbits are very common infections and represent a suitable model for studying the relationship between the infection and changes in metabolism. Staphylococcus aureus is a Gram-positive bacterium that produces several toxins (leucocidin, exfoliatin, haemolysin, enterotoxins and TSS-toxin 1), causing severe skin damages and a variety of systemic responses in the organism including Acute Phase Response (APR) and changes in blood trace elements (1). APR is a part of the innate immunity appearing before the specific

\footnotetext{
Correspondence to: $M$. Toneva, Department of Pharmacology, Physiology of the Animals and Physiological Chemistry, Faculty of Veterinary Medicine, Trakia University, Stara Zagora, Bulgaria, tel: +359 42699 636,E-mail: monika_ra4eva@abv.bg
}

immune response raised (2). This initial body reaction against pathological processes (e.g. trauma, infection, surgery, neoplastic growth, etc.) includes different changes such as leukocytosis and activation of macrophages and monocytes to synthesize pro-inflammatory cytokines that transform the hepatic protein spectrum and trigger Acute Phase Proteins (APP) secretion (3-5). In addition, several other tissues are able to synthesize APPs e.g. the lungs, ovaries, uterus, digestive tract, testes, adipose tissue and mammary glands (4). The main purpose of these changes is to restore the homeostasis by isolating and destroying the harmful agent; to activate repair processes and to prevent tissues and organs from more severe damages (6). The APPs are a large group of plasma proteins that are released very quickly (within the first few hours) into the bloodstream, where each performs various and specific 
functions $(6,7)$. Some of them are constantly secreted and released in the blood, while other are secreted only during the APR (6). The type of APP expression considerably varies between animals (8). In rabbits, the APP spectrum includes Creactive protein, haptoglobin, $\alpha 1$-macroglobulin and transferrin which are the most important positive APPs (9). Serum amyloid A (SAA) is also recognized as one of the most important positive APP in rabbits $(9,10)$. It is synthesized primarily by the liver, but extrahepatic secretion is also reported, e.g. smooth-muscle cells, intestinal epithelial cells and macrophages (3). Its function is not fully understood, but some activities have been described. Generally, SAA binds, transports and scavenges the cholesterol from the dying cells (4); inhibits the platelet aggregation (7) and detoxifies the endotoxins by binding to lipopolysaccharide (3). Also, SAA is able to bind to Gram-negative bacteria (11) and stimulate the migration of inflammatory cells to areas of altered tissues (12).

Iron is an essential trace element required for the normal course of various physiological processes in the living cells. As a part of hemoglobin, its main function is to transport oxygen from the lungs to the body tissues through the blood vessels. The iron is absolutely necessary for bacterial growth. In this connection, several defensive reactions in the host body during infections occur aiming to interfere iron utilization by pathogenic bacteria, which causes disorders of bacterial growth and replication. Some of these reactions include binding of hemoglobin to haptoglobin, which makes iron unavailable to microorganisms (13), storage of iron in hepatocytes (14), inhibition of intestinal absorption of iron (15), etc. However, if the iron concentration increases, oxidative stress may occur due to its well-pronounced redox activity. Therefore, iron balance is vital for the health of the body and its disturbance may lead to disease (16).

Given the above data, the present study aims to investigate the changes in concentrations of SAA and iron in rabbits, experimentally infected with $S$. aureus and to provide additional information for early diagnosis of rabbit skin staphylococcosis.

\section{MATERIAL AND METHODS}

The experiment was approved by the Bulgarian Food Safety Agency (Approval protocol №158/2016). The experimental procedures were carried out with 12 male New Zealand white healthy rabbits, divided into two equal groups experimental group $(\mathrm{n}=6)$ and control group $(n=6)$. The rabbits from each group were reared separately into two premises and were placed in previously disinfected individual metal cages with a grill floor, and at a constant temperature of about $20-22^{\circ} \mathrm{C}$. The animals were fed with granulated feed and have free access to water. It was provided a two-week acclimatization period before performing the infection in the experimental group. The experimentally induced staphylococcosis was reproduced by subcutaneous injection of the rabbits with $100 \mu \mathrm{L}$ of a bacterial suspension of $S$. aureus field strain (density: $8 \times 10^{8} \mathrm{cfu} / \mathrm{mL}$ ). The rabbits of the control group were injected with saline solution. The inoculation site (flank) was pre-shaved and prepared for manipulation. Blood samples were collected from each rabbit by venipuncture of $v$. auricularis caudalis into sterile heparinized tubes at time $0,24,48,72$ hours and also 7 and 14 days post-infection. The blood samples were centrifuged (1500 rpm x $10 \mathrm{~min}$ ); plasma was separated and frozen at $-20{ }^{\circ} \mathrm{C}$ until analyses. Thawed plasma was used for determination of SAA and iron. SAA $(\mu \mathrm{g} / \mathrm{mL})$ was determined using a multispecies enzyme linked immunosorbent assay. Briefly, samples were diluted 1:500 in 0.05\% Phosphate-buffered saline (PBS)-Tween and $100 \mu 1$ of the sample was added along with standards and controls to a 96 well plate. All approaches were done in duplicate. The plates were incubated at $37^{\circ} \mathrm{C}$ for $1 \mathrm{~h}$ and then washed four times using $300 \mu 1$ of PBS-Tween per well. After tapping to remove excess wash solution, $100 \mu$ l of a ready to use horseradish peroxidase labelled monoclonal antibody was added to the micro wells and the plate incubated for a further $30 \mathrm{~min}$ at $37^{\circ} \mathrm{C}$. The wells were then washed with PBS-Tween before $100 \mu l$ tetramethylbenzidine(TMB)-substrate was added for 10 minutes. The reaction was stopped by addition of $100 \mu \mathrm{l}$ of $0.1 \mathrm{M}$ sulphuric acid and the plate was read at an absorbance of $450 \mathrm{~nm}$ by photometer. Samples with a concentration above the highest measurable concentration were further diluted and retested. Iron $(\mathrm{Fe}, \mu \mathrm{g} / \mathrm{dL})$ concentration was determined with a biochemical analyser Olympus (Spain) at the Faculty of Veterinary Medicine at the Autonomous University of Catalonia, Barcelona, Spain. Statistical analysis was performed by means of ANOVA (Statistics for Windows, Stat Soft.) and the differences were considered significant at $\mathrm{p}<0.05$.

\section{RESULTS}

SAA values varied within a wide range between the experimental and control groups. As shown in Figure 1, SAA concentrations in the experimental group increased significantly at the $24^{\text {th }}$ hour $(\mathrm{p}<0.001), 48^{\text {th }}$ hour $(\mathrm{p}<0.05)$, and $72^{\text {th }}$ hour 
TONEVA M., et al.

$(\mathrm{p}<0.05)$ post-infection with mean levels $72.13 \pm$ $23.29 \mu \mathrm{g} / \mathrm{mL}, 37.57 \pm 31.55 \mu \mathrm{g} / \mathrm{mL}$ and $18.03 \pm$ $15.15 \mu \mathrm{g} / \mathrm{mL}$ respectively. Also, SAA levels decreased at the $7^{\text {th }}$ and $14^{\text {th }}$ days, reaching the baseline. In experimental rabbits, $\mathrm{Fe}$ concentration at the $24^{\text {th }}$ hour and $14^{\text {th }}$ day postinfection decreased significantly compared to the control animals, reaching values of $99,28 \pm 31,38$ $\mu \mathrm{g} / \mathrm{dL} \quad(\mathrm{p}<0.01)$ and $123,50 \pm 43,88 \mu \mathrm{g} / \mathrm{dL}$ $(\mathrm{p}<0.05)$ respectively (Figure 2$)$.

Figure 1: SAA content in control and infected groups of rabbits

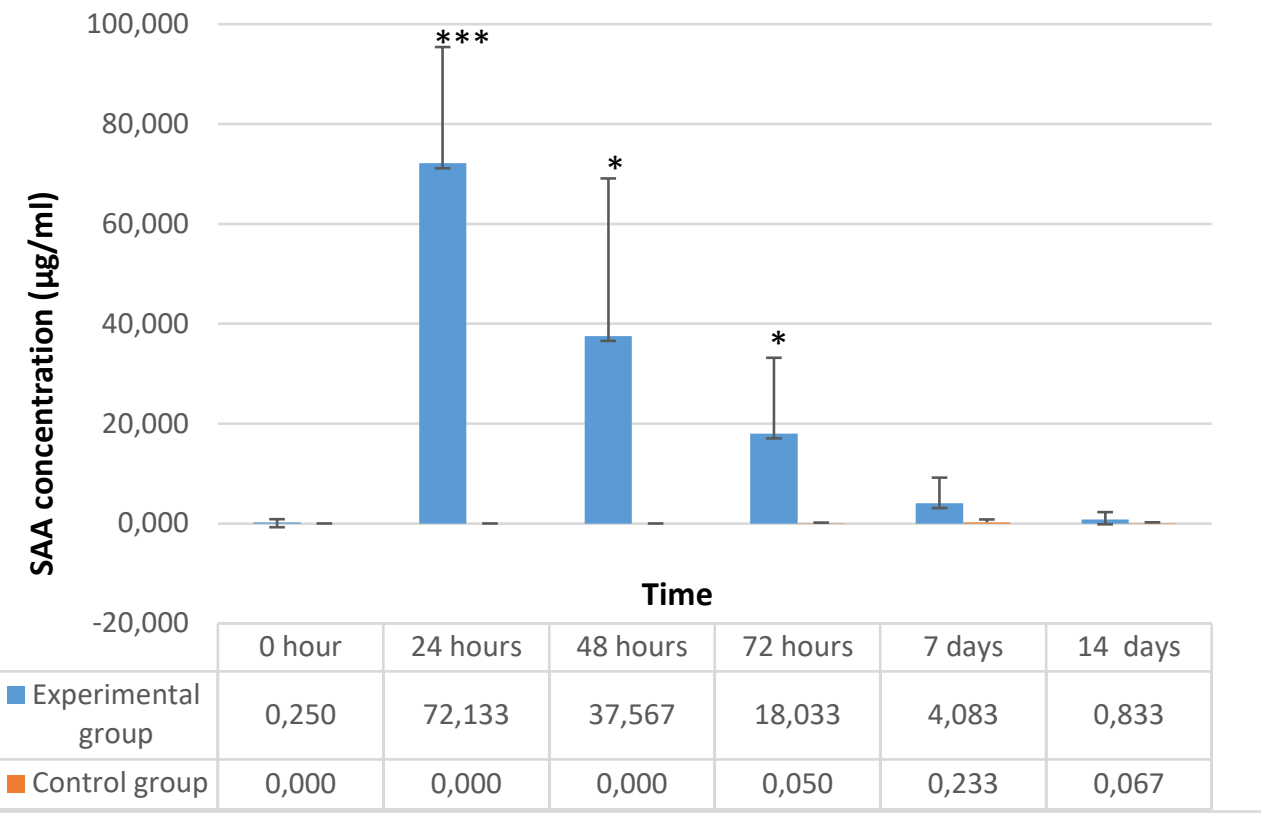

Statistically significant difference between control and experimental groups: $* \mathrm{p}<0.05 ; * * \mathrm{p}<0.01 ; * * * \mathrm{p}<0.001$

Figure 1. Changes in serum amyloid A concentration in rabbits experimentally infected with $S$. aureus Significance between groups $* \mathrm{p}<0.05 ; * * \mathrm{p}<0.01 ; * * * \mathrm{p}<0.001$

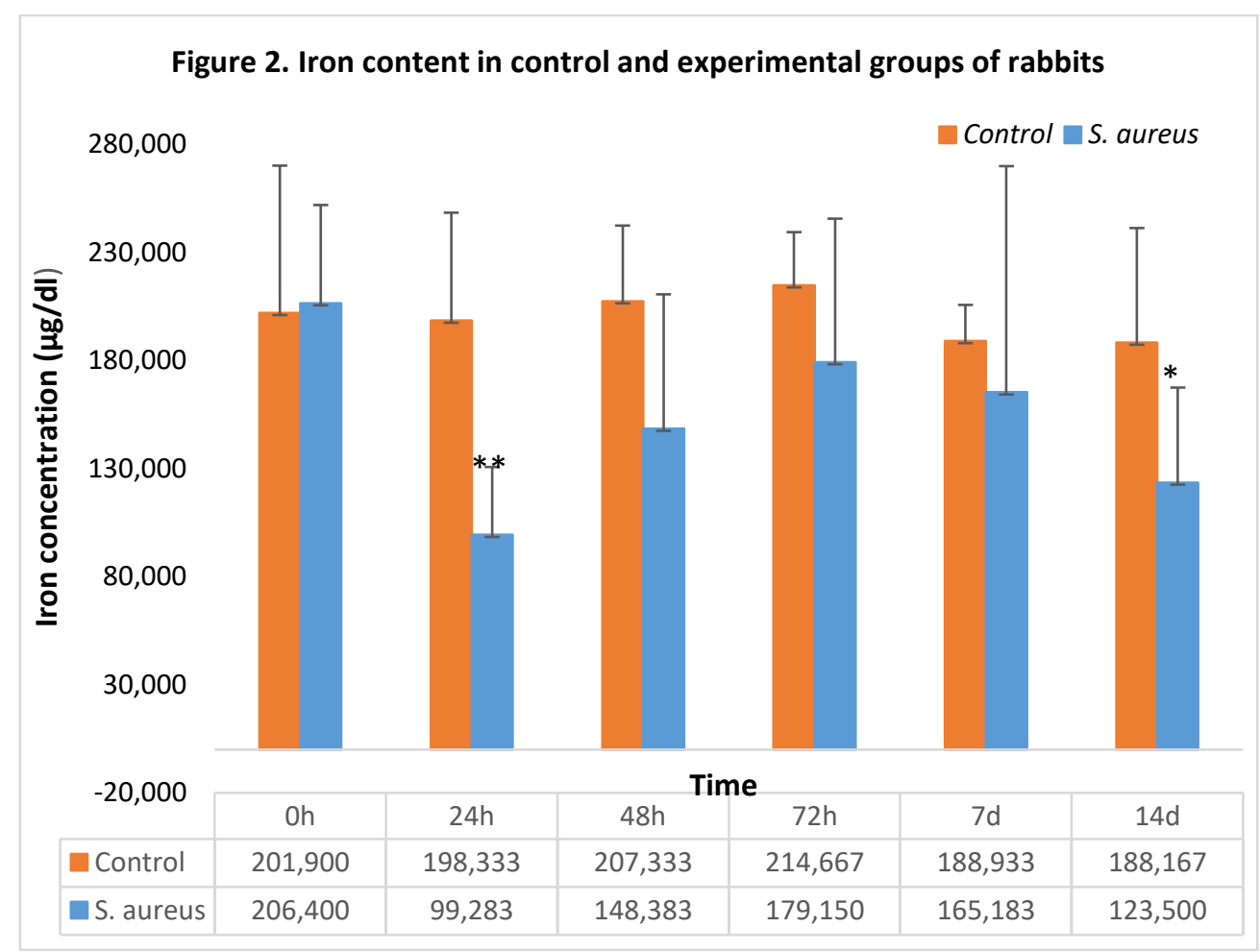

Statistically significant difference between control and experimental groups: $* \mathrm{p}<0.05 ; * * \mathrm{p}<0.01 ; * * * \mathrm{p}<0.001$

Figure 2. Changes in iron concentration in rabbits experimentally infected with $S$. aureus Significance between groups $* \mathrm{p}<0.05 ; * *_{\mathrm{p}}<0.01$ 


\section{DISCUSSION}

Data on changes in the blood levels of some APPs and trace elements during $S$. aureus infection in rabbits are still limited. The results of this study show that SAA increases extremely significant after infection with $S$. aureus. Cray (17) also reported an increase in the SAA concentration in rabbits with induced aseptic inflammation by applying turpentine oil. Similarly, the SAA levels increase in rabbits injected with lipopolysaccharides, casein and multiple inoculation of silver nitrate (17). According to Cray et al (18), there are no significant differences in SAA in rabbits infected with Encephalitozoon cuniculi. This might indicate that SAA does not actively participate in the APR in rabbits with encephalitozoonosis. The same authors found that only some of the animals demonstrate elevated SAA levels. Hadžimusić et all (19) established that after canine orchiectomy there is a rapid increase (within the first 24 hours after surgery) in the concentration of SAA and Creactive protein. Similarly, results of a study in dogs with pyometra revealed a significant increase in SAA and CRP concentrations (20). According to Hari-Dass et al (21), SAA plays a major role during infections with numerous bacterial pathogens. It acts as an opsonin, rapidly binding with high affinity many Gramnegative bacteria, such as Escherichia coli, Pseudomonas aeruginosa, Salmonella typhimurium, Shigella flexneri, Klebsiella pneumoniae and Vibrio cholerae (21).

Information on changes in $\mathrm{Fe}$ blood levels during $S$. aureus infection in rabbits is completely lacking in the available references. The results of this study show that iron significantly decreases which is most pronounced at the $24^{\text {th }}$ hour and $14^{\text {th }}$ day after the infection. 22 revealed that $\mathrm{Fe}$ concentration in rabbits infected with Trypanosoma brucei brucei declined at the $18^{\text {th }}$ day after the inoculation. Similarly, Baker et al (23) found a decrease in Fe levels in mice injected with endotoxins of E. coli or Brucella abortus, which is in general agreement with our findings. In this regard, William et al (24) reported that serum $\mathrm{Fe}$ in laboratory animals generally decreases after inoculation with lipopolysaccharide endotoxin, bacterial exotoxin, infectious microorganisms, or inflammatory agents. Such a reduction is recognized as a crucial protective mechanism aimed at preventing the use of Fe by pathogenic bacteria and therefore inhibiting bacterial replication. In contrast, an abnormal Fe availability in some clinical conditions may be the cause of fatal septicemia due to the fact that phagocytic cells are congested by the rapidly increasing number of multiplying microorganisms having free $\mathrm{Fe}$ access (25). In healthy people, the antibacterial capacity of the blood could not be maintained unless the level of iron is extremely low (25).

\section{CONCLUSION}

The results of this study show that SAA is a reliable marker for determination of $S$. aureus infection in rabbits. The changes in SAA and Fe levels may be used as valuable biochemical indicators for the diagnosis and prognosis of staphylococcosis in rabbits but more additional investigations are needed to demonstrate their full potential as diagnostic markers of the infection.

\section{REFERENCES}

1. Dishlyanova, E., Georgieva, T. M., Vlaykova, T. and Penchev G., I., Effect of Staphylococcus aureus infection on fibrinogen and plasma protein concentrations in experimentally obese rabbits. FAP, Wageningen, $\mathrm{AE}$, The Netherlands, 2013

2. Gruys, E., Toussaint, M. J. M., Niewold, T. A. and Koopmans, S. J., Acute phase reaction and acute phase proteins. $J$. Zhejing Univ. Sci. B, 6, 1045-1056, 2005

3. Murata, H., Shimada, N. and Yoshioka, M., Current research on acute phase proteins in veterinary diagnosis: an overview. The Vet. J., 168: 28-40, 2004

4. Ceciliani, F., Ceron , J. J., Eckersall, P. D. and Sauerwein H., Acute phase proteins in ruminants. J. Proteom., 75, 4207-4231, 2012

5. Tothova, S., Nagy, O. and Kovac, G., Acute phase proteins and their use in the diagnosis of diseases in ruminants: a review. Vet. Med., 59, 163-180, 2014

6. Iliev, P. T. and Georgieva, T. M., Acute phase proteins in sheep and goatsfunction, reference ranges and assessment methods: an overview. Bulg. J. Vet. Med, 21 (1): 1-16, 2018

7. Petersen, H. H., Nielsen, J. P. and Heegaard,P. M. H., Application of acute phase protein measurements in veterinary clinical chemistry. Vet. Res., 35, 163-187, 2004 
8. Kushner, I., Rzewnicki, D. and Samols, D., What does minor elevation of C-reactive protein signify? Am. J. Med., 119: 17-28, 2006

9. Krzysztof , K., Wojcicka-Lorenowicz, K. and Gliński, Z., Acute phase proteins in rabbits. Medycynavet, 59 (10): 864-867, 2003

10. Mackiewicz, A., Ganapathi, M. K., Schultz, D., Samols, D. Reese, J. and Kushner, I., Regulation of rabbit acute phase protein biosynthesis by monokines. Biochem. J., 253: 851-857, 1988

11. Tothova, C., Nagy, O., Seidel, H. and Kováč, G, Acute phase proteins as markers of diseases in farm animals., APPEASBHVD, Rijeka, Croatia, 2011

12. Uhlar, C. M. and Whitehead, A. S., Serum amyloid A, the major vertebrate acutephase reactant. Eur. J. biochem., 265: 501-523, 1999

13. Barclay, R., The role of iron in infection. Med. Lab. Sci., 42: 166-172, 1985

14. Beisel, W. R., Pekarek, R. S. and WanNemacher R. W., The impact of infectious disease on trace-element metabolism of the host. TEMA-2, Baltimore, MD, 1974

15. Beresford, C. H., Nealer, R. J. and Brooks, 0 . G., Iron absorption and pyrexia. The Lancet, 297: 568-572, 1971

16. Muckenthaler, M.U, Rivella, S., Hentze, M. W. and Galy, B., A red carpet for iron metabolism. Cell, 168: 344-61, 2017

17. Cray, C., Acute Phase Proteins in Animals. Prog. Mol. Biol. Transl. Sci., 105: 113150, 2012
18. Cray, C., Rodriguez, M. and Fernandez, Y., Acute Phase Protein Levels in Rabbits with Suspected Encephalitozoon cuniculi Infection. J. Exot. Pet Med., 22: 280-286, 2013

19. Hadžimusić, N. and Hrkovic, A., CReactive Protein and Serum Amyloid A in Male Dogs after Orchiectomy. J. Fac. Vet. Med., 15(1): 37-40, 2018

20. Jitpean, S., Holst, B. S., Höglund, O. V., Pettersson, A., Strage, E., Södersten, F. and Hagman, R., Serum insulin-like growth factor - I, iron, C-reactive protein, and serum amyloid A for prediction of outcome in dogs with pyometra. Theriogenology, 82: 43-48, 2014

21. Hari-Dass, R., Shah, C., Meyer, D. J. and Raynes, J. G., Serum amyloid A protein binds to outer membrane protein $\mathrm{A}$ of gram-negative bacteria. J Biol Chem., 280:18562-18567, 2005

22. Mwangi, M., McOdimba, F. and LoganHenfrey, L., The effect of Trypanosoma brucei brucei infection on rabbit plasma iron and zinc concentrations. Acta Trop., 59 (4): 283-91, 1995

23. Baker, P.J. and Wilson, J. B., Hypoferremia in mice and its application to the bioassay of endotoxin. $J B$., 90: 903910, 1965

24. William R. Beisel M.D., Trace Elements in Infectious Processes. Med. Clin. N. Am., 60 (4): 8331-849, 1976

25. Bullen, J.J., Ward, C.G., Rogers, H.J., The critical role of iron in some clinical infections. Eur J.Clin Microbiol Infect Dis., 10 (8): 613-617, 1991 